\title{
The ecological domain in the sustainability science research and education
}

\author{
${ }^{1}$ Marcin Pawel Jarzebski", ${ }^{2}$ Shogo Kudo \\ ${ }^{1}$ Integrated Research System for Sustainability Science (IR3S), The University of Tokyo Institute for Advanced Study, \\ The University of Tokyo, 7-3-1 Hongo, Bunkyo-ku, Tokyo, 113-8654, Japan, \\ e-mail: marcin.jarzebski@yahoo.com \\ ${ }^{2}$ Graduate Program in Sustainability Science - Global Leadership Initiative, Graduate School of Frontier Sciences, \\ The University of Tokyo, 5-1-5, Kashiwanoha, Kashiwa City, Chiba, 277-8563, Japan
}

\begin{abstract}
A single disciplinary approach fails to tackle problems threatening the sustainable development. Thus, the sustainability science - focused on the problem, normative, and covering many disciplines - has been developed and recognized as critical in creating solutions that could actually trigger a global change. As an example, environmental issues are no longer the problem to be solved within the ecological domain but the primary and complex sources of the problem must be analysed from the social, economic and technical perspectives as well, using methodological tools allowing for a variety of disciplines. This study provides a systematic review of publications related to sustainability and ecology, and briefly explains the role of environmental knowledge in the sustainability education. The study has shown that despite a common scepticism about combining qualitative and quantitative approaches the employment of miscellaneous disciplines has become a common approach and ecology in the context of sustainability goes beyond the ecological research. It appears from the reviewed curriculum of the sustainability science graduate programme at the University of Tokyo that environmental knowledge is well established, but is generally driven by transdisciplinary courses. It was included in the half of credits from compulsory courses, whereas elective courses are those which are open to other disciplines.
\end{abstract}

Key words: Sustainability Science, Ecological domain, Transdisciplinary.

\section{Introduction}

\subsection{Sustainability Science - origin of a new discipline}

Presently, human activities are reaching the limit of ecosystem capacity and persistent development challenges are continuously emerging (Griggs et al., 2013; Rockström et al., 2009). The climate change, environmental degradation, natural disasters, increasing poverty and human security, and rapid urbanization are so called super-wicked problems (Jerneck et al., 2011). These problems have complex structures and single solutions cannot solve the status quo (Lazarus, 2009; Levin et al., 2012; Rittel \& Webber, 1973). As a response for such problems, sustainability science has emerged as a vibrant academic discipline (Wiek et al., 2011).
Sustainability itself is a capability of maintaining at certain desirable state (Kajikawa, 2008). The complexity of those super-wicked problems is beyond the scope of mono-disciplinary science, and creating possible solutions requires the integration of social and natural sciences (Clark \& Dickson, 2003). In order to actualize such comprehensive approach to sustainability challenges, sustainability science is "defined more by the problems it addresses rather than the disciplines it employs" (Clark, 2007).

Seminal works in sustainability science literature mentions that the central focus of the discipline is to elucidate the complex, dynamic interactions between nature and society that we highlighted as the solution generating approach (Clark \& Dickson, 2003; Kates, 2011; Kates et al., 2001; Ostrom et al., 2007). The importance of these interactions was already emphasized in 1972, during the United 
Nations Conference on the Human Environment (UNEP, 1972), providing a ground for the sustainable development concept institutionalization at World Commission on Environment and Development in 1987 (UN, 1987). Reflecting the significance of the sustainable development concept, some scholars stress the knowledge contribution of sustainability science for achieving the goal (Martens, 2006; Parris \& Kates, 2003). The sustainability science examines also the inter-scale interactions among Global, National, and Social systems (Komiyama \& Takeuchi, 2006).

\subsection{Sustainability Science research - trans- disciplinary problem driven science}

Despite its relatively young history, sustainability science has attracted wide range of publications and it has formed a distinctive academic landscape (Bettencourt \& Kaur, 2011; Kajikawa et al., 2007; Kajikawa et al., 2014; Kates, 2011; Yarime et al., 2009). To date, it can be said that the core structure of sustainability science has been formed and its key features such as problem-driven and solution-oriented approach, transdisciplinary stand, and normative discourse have been identified (Brandt et al., 2013; Clark, 2007; Jerneck et al., 2011; Kajikawa, 2008; Lang et al., 2012; Spangenberg, 2011; Tainter, 2010; Wiek et al., 2011).

While problem-driven and solution-oriented approach will remain as one of the key features of sustainability science (Miller et al., 2014), especially given the fact that solutions need to be provided through parallel efforts on analyzing or identifying the problems (Komiyama \& Takeuchi, 2006), one remaining challenge for the discipline is to go beyond this problem-based and solution-oriented perspective. This is because what we identify as sustainability challenges are likely to change over time as sustainability is a normative concept. What we consider to be key elements differs depending on at which unit and contexts we articulate the sustainability concept. Subsequently, constant review of proposed solutions is necessary as sustainable society may also change. Challenges of sustainability are also revised based on progress in solving them, e.g., the United Nations make an effort in identifying problems and goals of sustainability, setting first Millennium Development Goals (MDGs), during Millennium Summit in 2000, set for 15 years. These goals were succeeded in 2015 by the 17 Sustainable Development Goals that supposed to be achieved by 2030, set by United Nations General Assembly (Costanza et al., 2016).

The research on the sustainability science involves all disciplines such as agriculture, economics, engineering, fishery, forestry, sociology, water resource, and climate sciences. There are three levels of integration of these disciplines into research, namely multidisciplinary, interdisciplinary, and transdisciplinary (Kajikawa, 2008). The transdisciplinary approach can only create the knowledge body for sustainability science and the two others can assist in shaping the structure of sustainability science. The interdisciplinary and multidisciplinary are working individually under each discipline or jointly but not rigorously in each one, unlike the transdisciplinary approach creating unique knowledge that still remain related to all conventional fields (Kajikawa, 2008). Traditional disciplines within ecological, economical, and social domains are being replaced by an approach that contains number of disciplines working together.

\subsection{Sustainability Science Education}

Along with the research development in sustainability science, it is critical for the field to establish its educational component, especially in higher education. The earlier literature argues that there has been a high demand on integrating the sustainable development concept into higher education in order to train individuals with higher awareness of sustainability, and who hold key competencies for problem analysis as well as solving, together with leadership skills to guide social transformations towards sustainable society (Brundiers \& Wiek, 2011; Calder \& Clugston, 2003; Cortese, 2003; Wiek et al., 2011). Despite the fact that the integration of environmental sustainability in higher education has been recognized as very important in several national and international declarations since the Stockholm Declaration in 1972, its actual implementation has remained as a challenge for universities because of the compartmentalization, over-specification, and reductionistic orientations of universities. In the reality, the sustainable development concept is only partially adapted in specific department (Lozano, 2010). Today, these courses on sustainability are offered as a part of larger curriculum or educational program such as Environmental Studies, Urban Engineering, and Development Studies.

Sustainability science in practice requires additional special set of competencies in order to enable the change in the system into sustainable state. System thinking, anticipatory, normative, strategic and interpersonal competences were suggested by Wiek et al. (2011). Additionally, co-design and co-creation of knowledge with stakeholders is also suggested as an important dimension of sustainability science, however reflecting such unique feature of sustainability science in an educational program is challenging. Achieving by a prospective researcher a mindset for "transdisciplinary-ready" in actual research projects is of the best results that sustainability science education can provide (Spangenberg, 2011). 


\subsection{The study problem and the objective}

The current research in sustainability science is problem driven and oriented towards more transdisciplinary approach. To evaluate the progress of such multi- or transdisciplinary approach is necessary to identify how different domains are treated by research. As a primary example, in the sustainability science research the ecological domain that initially concerned the environmental degradation issues supposed to be integrated with other disciplines to tackle the phenomenon with its plural causes. Simultaneously, education in the sustainability science field should be preparing young generation of practitioners and academicians to be ready to undertake research involving multiple disciplines, including disciplines from the ecological domain.

In light of the points mentioned above regarding requirements for sustainability science, the objective of the paper to explain the current position of ecological domain in the sustainability science research and education, as well as current trends and challenges in the current research state. The study will try to identify to what extend the ecological domain is retained and stressed in the sustainability science research and education, and subsequently to what extend such research and education becomes a transdisciplinary one.

\section{Materials and methods}

\subsection{Systematic review of journal paper}

To determine the presence of the sustainability in ecological research, the systematic review of research papers was conducted through ScienceDirect (http://www.sciencedirect.com/) academic paper search engine. Two key-words in the title and abstract: sustainability and sustainable (sustainab*), and ecology and ecosystem (ecolog* or ecosystem) as queries were set, for journal papers in the field of Agricultural and Biological Sciences. It gave 4,941 papers matching above criteria (excluding year 2017, as of November 18,2016$)^{1}$. The search results were sorted by relevance and a $10 \%$ cent sample was drawn from papers published in 2016 (631 search results for 2016). The first 63 of the most relevant papers were selected and reviewed through the lens of selected sustainability science research-related variables (Table 1).

\subsection{Review of curriculum}

The curriculum one of the pioneering program for sustainability science, the Graduate Program in Sustainability Science, The University of Tokyo, has been reviewed based on published online information (http://www.sustainability.k.u-tokyo.ac.jp/, accessed on December 10): Graduate

1 Search results: 4,991 results found for TITLE-ABSTR-KEY(ecolog* or ecosystem) and TITLE-ABSTR-KEY(sustainab*)[All Sources(Agricultural and Biological Sciences)]

Table 1. Variables used and their definitions

\begin{tabular}{|l|l|}
\hline Variable & Definition \\
\hline Problem driven & Research immediate response to an urging problem \\
\hline Sustainability goal oriented & The research address SDGs in any degree \\
\hline SDGs & Sustainable Development Goals addressed in the paper \\
\hline Scale & The scale of the research from local, regional, national, global to multi-scale \\
\hline Time & The time concerned by the research - past, present, future, and multiple time \\
\hline Domains & $\begin{array}{l}\text { Research in its problem and concepts covers social, ecological, economic, and technology } \\
\text { domain }\end{array}$ \\
\hline Methodology type & Methodology applied is qualitative; quantitative; or mix-method \\
\hline Disciplinarity & Research is mono or more than one discipline in applied methodology \\
\hline Disciplines & Named disciplines used in the methodology \\
\hline Results & $\begin{array}{l}\text { The results are base line (current state); predictive (models); covering current state and predict } \\
\text { possible future scenarios, or a framework }\end{array}$ \\
\hline
\end{tabular}




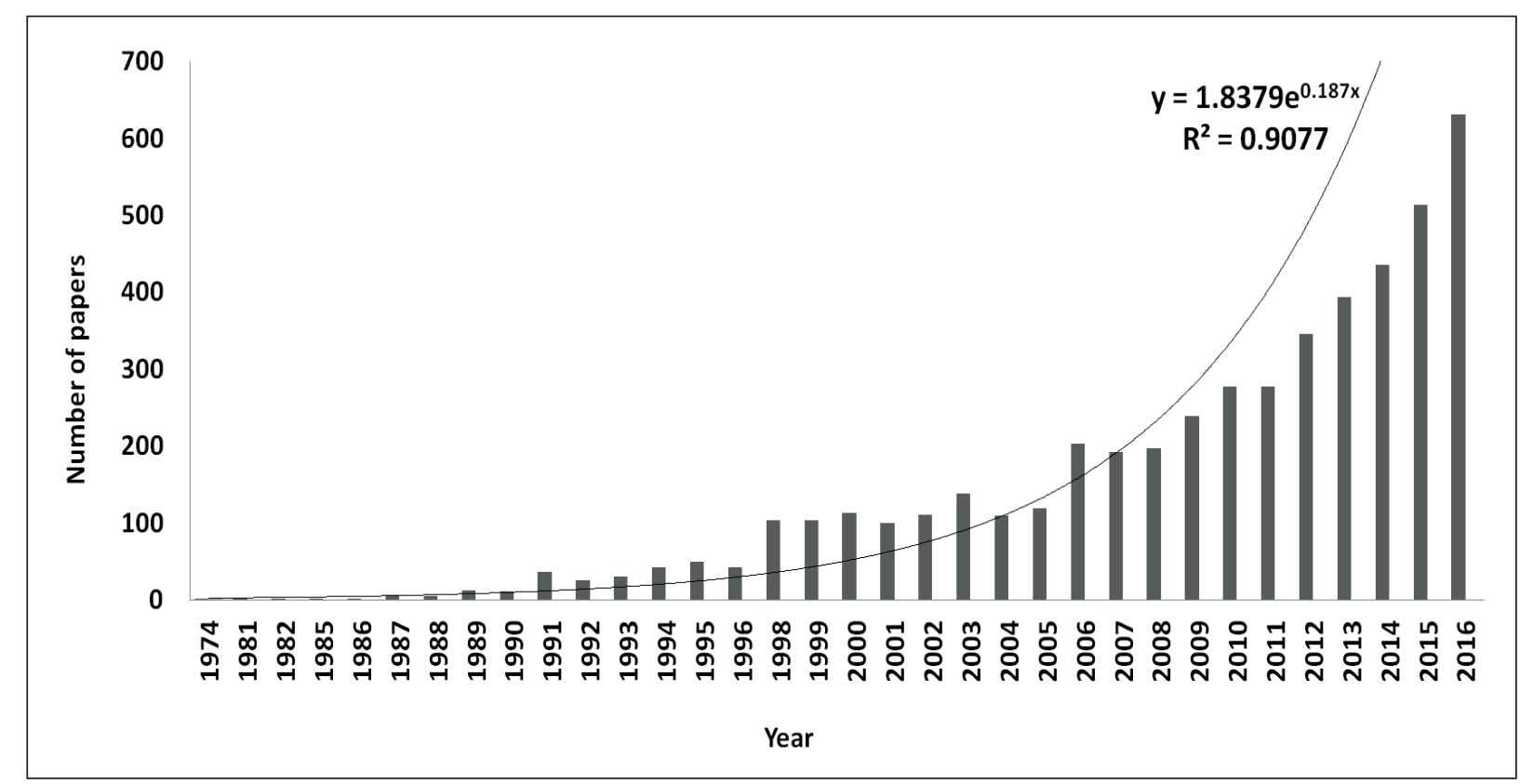

Figure 1. Number of publications concerning ecology and sustainability

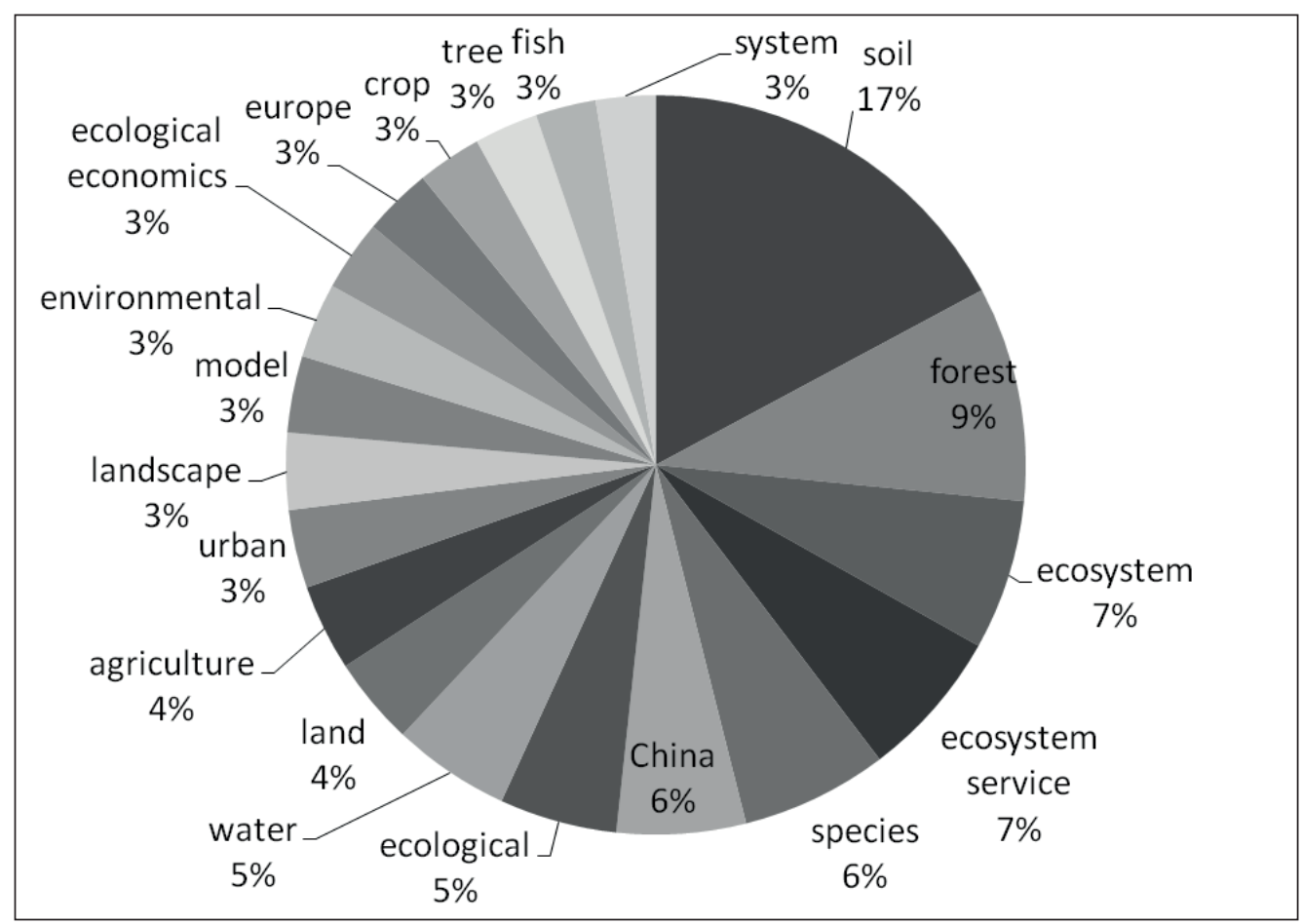

Figure 2. Share of the topics covered in reviewed papers 
Program in Sustainability Science - Global Leadership Initiative Course List, Academic Year 2016-2017 for master and doctoral program. The curriculum was reviewed to ecological domain elements present in the course main theme.

\section{Results}

\subsection{Journal papers characteristic}

The results shows that papers containing ecology and sustainability issues have been on exponential increase, especially since late 1990s (Fig. 1). The ten most popular journals publishing papers related to ecology and sustainability, in the field of agricultural and biological sciences, are presented in the Table 2. In the same time, each of these journals are all journals which published above 100 of such papers. The research papers published with the searched keywords were related to number of topics. The most frequently covered topics were soil, forest, ecosystem and ecosystem services. The other sixteen topics are represented by 6 and below per cent of total number of topics (Fig. 2).

\subsection{The characteristic of the research containing the ecological aspects}

The overarching characteristics of reviewed 10 per cent sample papers published in 2016 are presented in the Table 3 . The research were strongly driven by problem in $33 \%$, but majority of papers were concerning SDGs, three domains, and using methodology based on three and more disciplines. Majority of papers applied either the qualitative or quantitative methodology. Only small share of papers had predictive outcome or crossing time and scales. Main sustainability science characteristics of reviewed papers are presented in Table 3 . The most frequently addressed SDGs in the papers were concerning SDG 15, the life of land that refers to various aspects of terrestrial eco-
Table 2. The ten academic journals which published identified papers

\begin{tabular}{|l|l|c|}
\hline No. & \multicolumn{1}{|c|}{ Publication title } & $\begin{array}{c}\text { Number of } \\
\text { publications }\end{array}$ \\
\hline 1 & Ecological Economics & 580 \\
\hline 2 & Forest Ecology and Management & 398 \\
\hline 3 & Agriculture, Ecosystems \& Environment & 306 \\
\hline 4 & Ecological Indicators & 296 \\
\hline 5 & Ecological Modelling & 239 \\
\hline 6 & Landscape and Urban Planning & 237 \\
\hline 7 & Marine Policy & 212 \\
\hline 8 & Ecological Engineering & 197 \\
\hline 9 & Land se Policy & 157 \\
\hline 10 & Biological Conservation & 143 \\
\hline
\end{tabular}

systems ecology. Two other top goals that papers referred to were SDG 14 concerning life below water, and SDG 2 referring to hunger reduction and sustainable agriculture with special emphasis on the latter component (Table 4). Concerned domains were ecological in $100 \%$, expectedly as it was set as one of the criterion of the search, social in $75 \%$, economic in $71 \%$, and technology in $13 \%$. Subsequently, the most frequently used methodology in the research were from fields of earth sciences, agriculture, biology, sociology, engineering, economics (Fig. 3). In the methodology used, the most dominant connection between disciplines were earth sciences and engineering (11 connections out of total 71 recorded).then between earth sciences and biology (9), physics and chemistry (6), engineering and biology (5), economics and biology (4), and between agriculture and modelling (4). Other disciplines were found to be connected not more than 3 times (Fig. 4).

Table 3. Major sustainability science research characteristics in reviewed papers

\begin{tabular}{|c|c|c|c|c|c|c|c|c|c|}
\hline \multicolumn{2}{|c|}{ Problem } & \multicolumn{2}{|c|}{ Domains concerned } & \multicolumn{2}{|c|}{ Disciplinarily } & \multicolumn{2}{|c|}{ Outcome } & \multicolumn{2}{|c|}{ Multi-scalar } \\
\hline 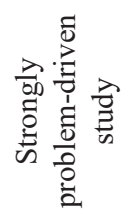 & 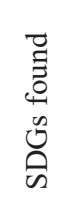 & $\stackrel{0}{3}$ & 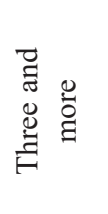 & 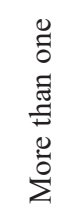 & 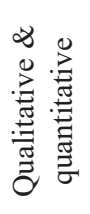 & 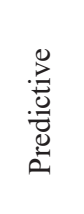 & 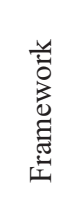 & 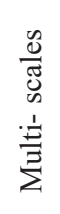 & $\begin{array}{l}\stackrel{\mathscr{\Xi}}{\Xi} \\
. \stackrel{!}{E} \\
\dot{\Xi}\end{array}$ \\
\hline $33 \%$ & $87 \%$ & $10 \%$ & $68 \%$ & $43 \%$ & $11 \%$ & $14 \%$ & $16 \%$ & $3 \%$ & $14 \%$ \\
\hline
\end{tabular}


Table 4. Ranking of the most frequent SDG concerned in reviewed papers

\begin{tabular}{|l|c|}
\hline Sustainable Development Goal & Frequency \\
\hline $\begin{array}{l}15 \text { - Protect, restore and promote sustainable } \\
\text { use of terrestrial ecosystems, sustainably } \\
\text { manage forests, combat desertification, and } \\
\text { halt and reverse land degradation and halt } \\
\text { biodiversity loss }\end{array}$ & $32 \%$ \\
\hline $\begin{array}{l}14-\text { Conserve and sustainably use the oceans, } \\
\text { seas and marine resources for sustainable } \\
\text { development }\end{array}$ & $17 \%$ \\
\hline $\begin{array}{l}2-\text { End hunger, achieve food security and } \\
\text { improved nutrition and promote sustainable } \\
\text { agriculture }\end{array}$ & $16 \%$ \\
\hline $\begin{array}{l}11-\text { Make cities and human settlements } \\
\text { inclusive, safe, resilient and sustainable }\end{array}$ & $10 \%$ \\
\hline $\begin{array}{l}12-\text { Ensure sustainable consumption and } \\
\text { production patterns }\end{array}$ & $10 \%$ \\
\hline $\begin{array}{l}13-\text { Take urgent action to combat climate } \\
\text { change and its impacts }\end{array}$ & $7 \%$ \\
\hline $\begin{array}{l}6-\text { Ensure availability and sustainable } \\
\text { management of water and sanitation for all }\end{array}$ & $4 \%$ \\
\hline $\begin{array}{l}9-\text { Build resilient infrastructure, promote } \\
\text { inclusive and sustainable industrialization and } \\
\text { foster innovation }\end{array}$ & $3 \%$ \\
\hline
\end{tabular}

Note. The thickness of notes and the score represent the number of connections. The network was generated with Cytoscape 3.4.0. software (U.S. National Institute of General Medical Sciences)

\subsection{Review of Sustainability Science Curriculum}

The curriculum of the Graduate Program in Sustainability Science (GPSS) delivers subjects that are at the graduate level, excluding courses delivering basic knowledge from any disciplines. Courses are classified into basic compulsory courses on sustainability science, compulsory elective lecture courses, advanced compulsory courses on sustainability science, elective courses, exercises, global leadership exercise. Additionally master and doctoral research are counted as thesis-related courses (for 8 and 12 credits respectively); and two credits (one or two courses) can be taken from courses given by other departments.

\section{Discussion and conclusion}

The number of papers covering ecological and sustainability keywords has been on exponential increase over past few decades. The first paper with key "sustainable" and "ecology"-related keywords was already published in early 1970s, concerning environmental impacts of a highway construction on flora and fauna in the Amazon basin (Goodland \& Irwin, 1974). The paper was published after the United Nations Conference on the Human Environment but yet a decade before the concept of sustainable development was declared at the World Commission on

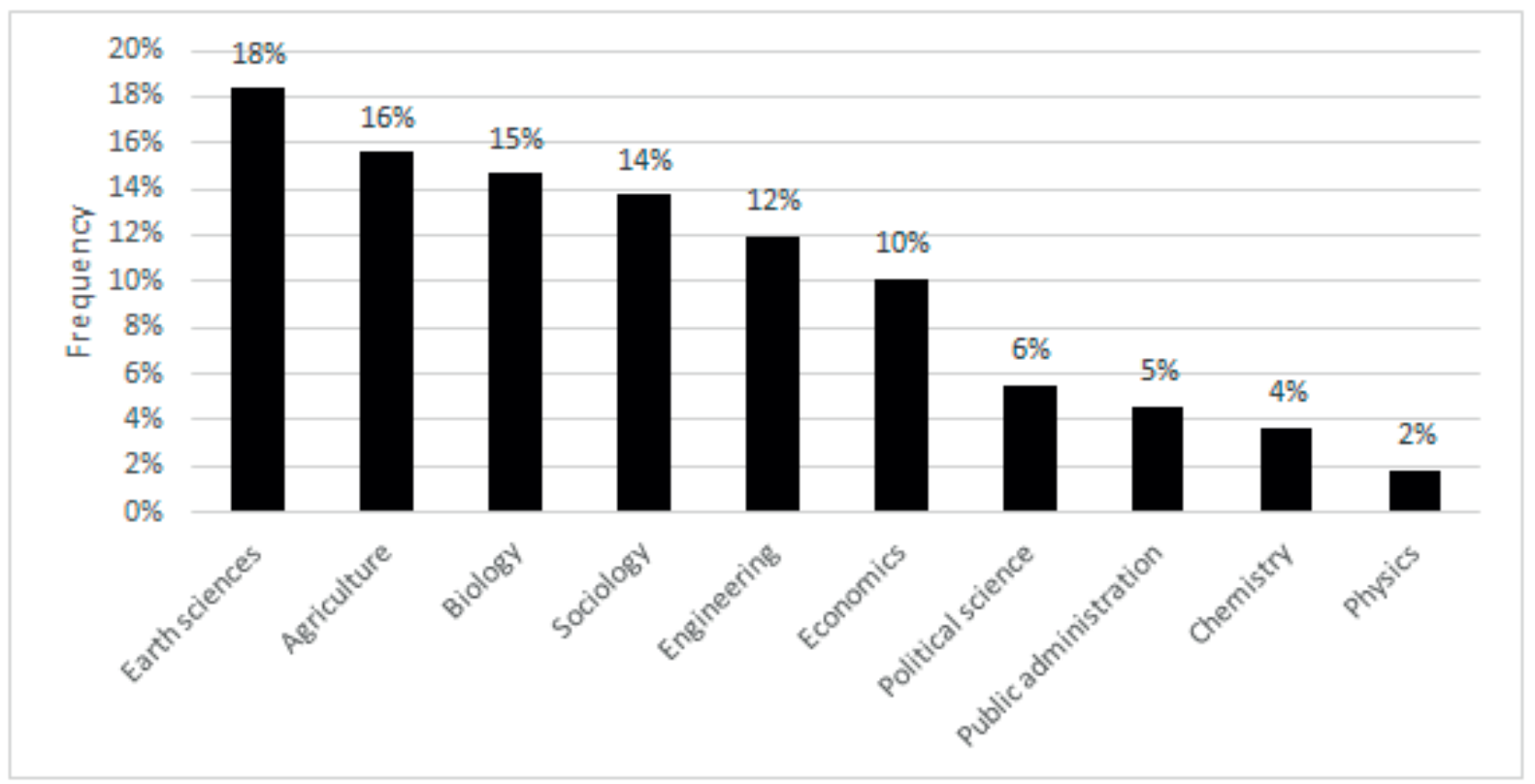

Figure 3. Disciplines used in the methodology of reviewed papers 
Environment and Development. The sustainability theme in the research has been sharply increasing in the research since acknowledgement of sustainable development goal by the international community. Number of papers including both, ecology- and sustainability-derived words reached circa one hundred in 2000, with six fold published in 2016 (Fig. 1). Most concerned keywords were related to soil, forest, ecosystem and ecosystem services (Fig. 2). These keywords suggest that soil erosion, deforestation and ecosystem services degradation have been the most urging problems of sustainability with the ecological domain concerned. The leading journal that was publishing papers found for this review was the Ecological Economics, a journal which is integrating ecology and economy in order to integrate environmental and economic policies for their mutual benefit (http://www.journals.elsevier.com/ ecological-economics/). This journal is open for a free methodology set, promoting transdisciplinary study which is corresponding with the concept of sustainability science.

The most up-to-date papers demonstrated development of sustainability science as a discipline already. They reflect on multidisciplinarity in the set of used methods for crafting the research, based on three and more disciplines. Sciences such as earth sciences and biology tend to integrate with each other and with engineering (such various IT technologies, Geographic Information System and models). Thus ecology and sustainability related research is no

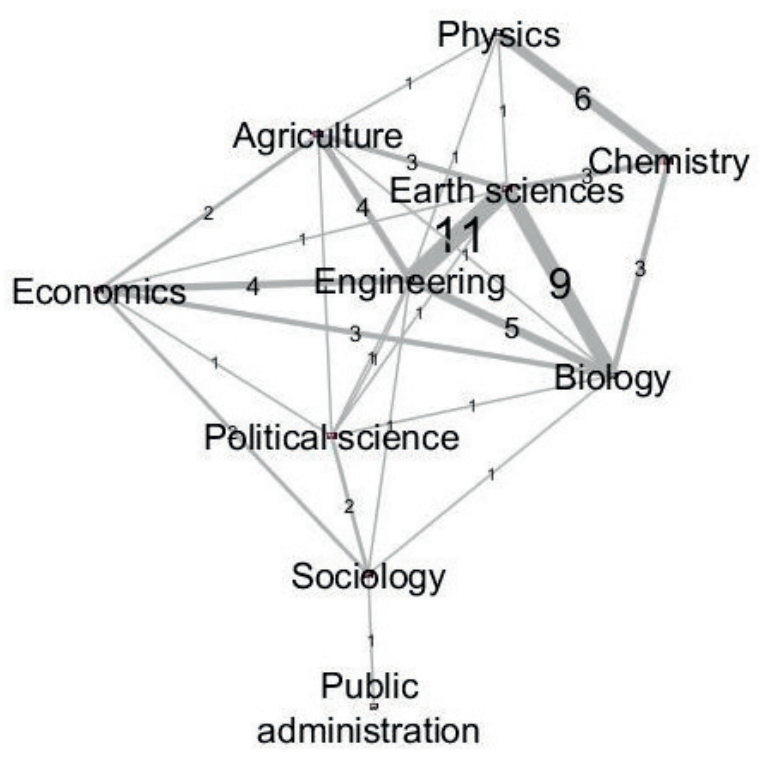

Figure 4. Disciplinarily network

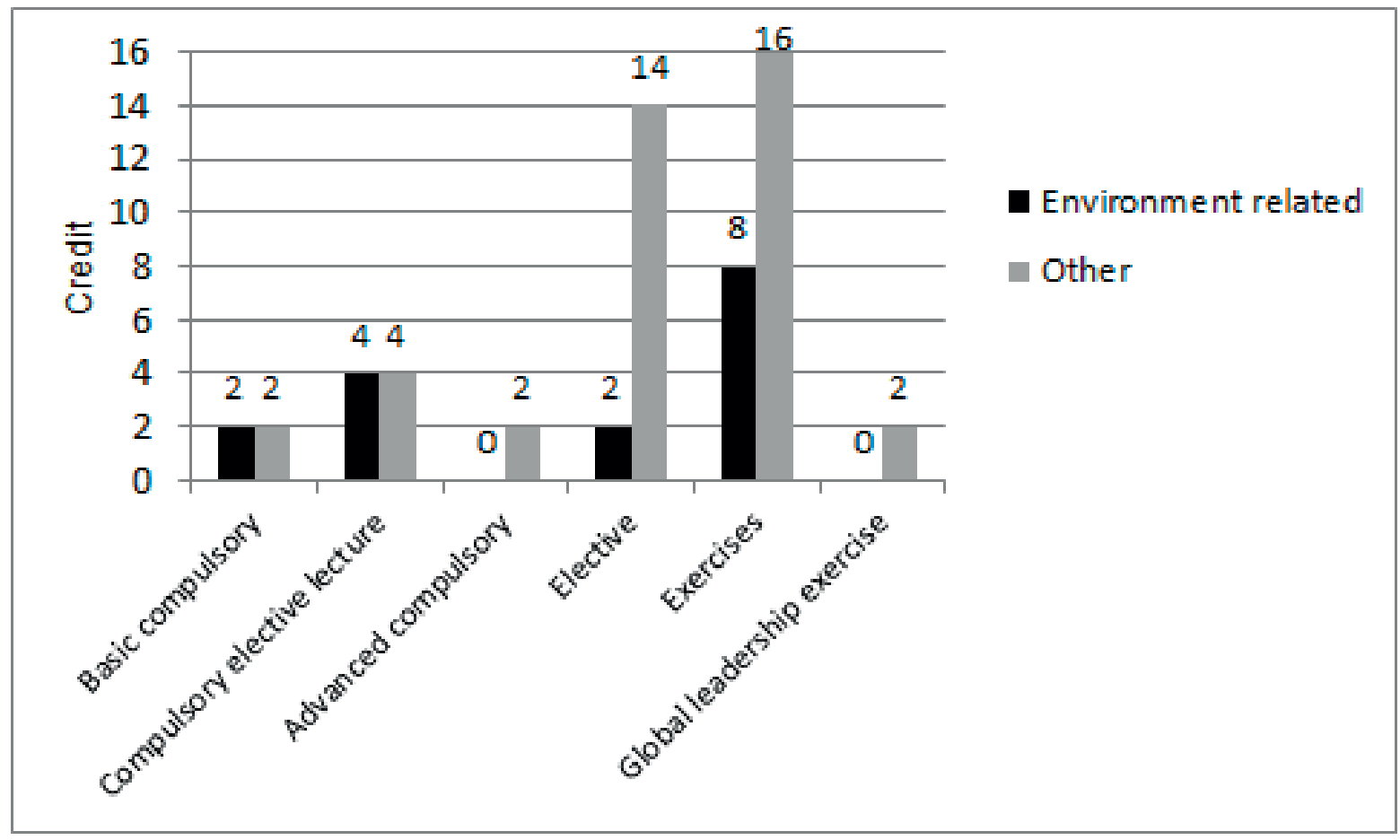

Figure 5. Course type and allocated number credits 
longer designed only from one discipline side. However, methodology remains quantitative or qualitative. The majority of papers were concerning at least three domains, using various set of methodologies but either the qualitative or quantitative set, and not necessarily as the response for critical sustainability problems that need immediate action. Most frequently addressed by papers goal were classified as SDG 15 (32 per cent) which refers to protecting terrestrial ecosystems, including maintaining biodiversity, halting deforestation and other ecological degradation on land. Two other most frequently addressed goals were SDG 14 on sustainable use and protection of marine resources (17 per cent) and SGD2 on sustainable agriculture and food supply (16 per cent). Small share of papers delivered predictive outcome or covered multiple time and scales. However, reviewed papers which were proposing frameworks recommended transdisciplinary sustainability frameworks as the outcome with use of combination of qualitative and quantitative (e.g. climate change strategies for fishery in Busch et al., 2016).

The education in the field of sustainability science prepares young scientists and practitioners into employing sustainability science. The curriculum of Graduate Program in Sustainability Science at the University of Tokyo is focused on courses developing skills for responding to sustainability problems based to more than one discipline. Ecology and environment related course are still one of the main themes in the basic and compulsory elective lectures, accounting respectively for 2 and 4 credits, same number as other courses. In the exercises, the environment related courses accounts for 8 credits, whereas 16 can be awarded by other courses. For other elective courses the environment related subjects are already minority on the course list. As comparison, the study of 27 master's degree programs worldwide ${ }^{2}$ conducted by O'Byrneet al. (2015) demonstrated that the curriculum of graduate level of programs shift towards more transdisciplinary and applied aspects of various sciences, in which environment related courses cover more selectively sustainability-related problem areas such as water, climate or energy under applied sustainability courses.

Research concerning ecology and sustainability science encompasses multiple disciplines, broadly concerning issues of terrestrial ecosystem, marine resources and agriculture. However, these issues are no longer the problem of one ecological domain but they involve other domains, especially social and economic, employing different disciplines of science but either their qualitative or quantitative aspects. The interests of the researches in relating the research to sustainability has been growing, accelerating

\footnotetext{
2 Study included Graduate Program in Sustainability Science at the University of Tokyo.
}

publishing numbers since late 1990s. Reviewed graduate level program in sustainability science located at the University of Tokyo demonstrates the environment-related knowledge is still one of the core subject embedded into transdisciplinary courses.

\section{Limitations}

The limitation of the study is using the ScienceDirect search engine which is limiting the search to journals from Elsevier publisher. However, as a sampling method tool this search engine was advantage for this study providing coherent source of scientific papers.

\section{References}

Bettencourt L.M.A., Kaur J., 2011, Evolution and structure of sustainability science, Proceedings of the National Academy of Sciences of the United States of America, 108(49): 19540-5. [http://doi.org/10.1073/ pnas.1102712108].

Brandt P., Ernst A., Gralla F., Luederitz C., Lang D.J., Newig J. \& Von Wehrden H., 2013, A review of transdisciplinary research in sustainability science, Ecological Economics 92: 1-15. [http://doi.org/10.1016/j. ecolecon.2013.04.008].

Brundiers K. \& Wiek A., 2011, Sustainability research education in real- world settings - vision and implementation, Innov. High Educ. 36: 107-124.

Busch D.S., Griffis R., Link J., Abrams K., Baker J., Brainard R.E. \& Merrick R., 2016, Climate science strategy of the US National Marine Fisheries Service, Marine Policy 74: 58-67. [http://doi.org/10.1016/j.marpol.2016.09.001].

Calder W. \& Clugston R., 2003, International Efforts to Promote Higher Education for Sustainable Development, Planning for Higher Education 31 (3): 30-44.

Clark W.C., 2007 (February), Sustainability science: a room of its own, Proceedings of the National Academy of Sciences of the United States of America. [http:// doi.org/10.1073/pnas.0611291104].

Clark W.C. \& Dickson N.M., 2003, Sustainability science: the emerging research program, Proceedings of the National Academy of Sciences of the United States of America 100(14) 8086-8091. [http://doi.org/10.1073/ pnas.1231333100].

Cortese A.D., 2003, The Critical Role of Higher Education in Creating a Sustainable Future, Planning for Higher Education, March-May: 15-22.

Costanza R., Daly L., Fioramonti L., Giovannini E., Kubiszewski I. \& Fogh L., 2016, Measuring sustainable wellbeing in connection with the UN Sustainable 
Development Goals, Ecological Economics 130: 1-8. [http://doi.org/10.1016/j.ecolecon.2016.07.009].

Goodland R.J.A. \& Irwin H.S., 1974, An ecological discussion of the environmental impact of the highway construction program in the Amazon basin, Landscape Planning 1: 123-254. [doi:10.1016/0304-3924(74)90018-5].

Griggs D., Stafford-Smith M., Gaffney O., Rockström J., Ohman M.C., Shyamsundar P. \& Noble I., 2013, Sustainable development goals for people and planet, Nature 495(7441): 305-7. [http://doi.org/10.1038/495305a].

Jerneck A., Olsson L., Ness B., Anderberg S., Baier M., Clark E. \& Persson J., 2011, Structuring sustainability science, Sustainability Science 6(1): 69-82. [http://doi. org/10.1007/s11625-010-0117-x].

Kajikawa Y., 2008, Research core and framework of sustainability science, Sustainability Science 3(2): 215239.[http://doi.org/10.1007/s11625-008-0053-1].

Kajikawa Y., Ohno J., Takeda Y., Matsushima K. \& Komiyama H., 2007, Creating an academic landscape of sustainability science: an analysis of the citation network, Sustainability Science, 2(2): 221-231. [http:// doi.org/10.1007/s11625-007-0027-8].

Kajikawa Y., Tacoa F. \& Yamaguchi K., 2014, Sustainability science: the changing landscape of sustainability research, Sustainability Science 9(4): 431-438. [http:// doi.org/10.1007/s11625-014-0244-x].

Kates R.W., 2011, What kind of a science is sustainability science? Proceedings of the National Academy of Sciences 108(49): 19449-19450. [http://doi. org/10.1073/pnas.1116097108].

Kates R.W., Clark W.C., Corell R., Hall J.M., Jaeger C.C., Lowe I. \& Svedin U., 2001, Sustainability Science, Science 292(5517): 641-642. [http://doi.org/10.1126/ science.1059386].

Komiyama H. \& Takeuchi K., 2006, Sustainability science: building a new discipline, Sustainability Science 1(1): 1-6. [http://doi.org/10.1007/s11625-006-0007-4].

Lang D.J., Wiek A., Bergmann M., Stauffacher M., Martens P., Moll P. \& Thomas C.J., 2012, Transdisciplinary research in sustainability science: practice, principles, and challenges, Sustainability Science 7(S1): 25-43. [http://doi.org/10.1007/s11625-011-0149-x].

Lazarus R.J., 2009, Super Wicked Problems and Climate Change: Restraining the Present to Liberate the Future, Change 1234: 10749-10756.

Levin K., Cashore B., Bernstein S. \& Auld G., 2012, Overcoming the tragedy of super wicked problems: Constraining our future selves to ameliorate global climate change, Policy Sciences 45(2): 123-152. [http://doi. org/10.1007/s11077-012-9151-0].

Lozano R., 2010, Diffusion of sustainable development in universities' curricula: an empirical example from Cardiff University, Journal of Cleaner Produc- tion 18(7): 637-644. [http://doi.org/10.1016/j.jclepro.2009.07.005].

Martens P., 2006, Sustainability : science or fiction? Sustainability: Science, Practice, Policy 2(1): 36-41.

Miller T.R., Wiek A., Sarewitz D., Robinson J., Olsson L., Kriebel D. \& Loorbach D., 2014, The future of sustainability science: A solutions-oriented research agenda, Sustainability Science 9(2): 239-246. [http://doi. org/10.1007/s11625-013-0224-6].

O’Byrne D., Dripps W. \& Nicholas K.A., 2015, Teaching and learning sustainability: An assessment of the curriculum content and structure of sustainability degree programs in higher education, Sustainability Science 10(1): 43-59. [http://doi.org/10.1007/s11625-0140251-y].

Ostrom E., Janssen M.A. \& Anderies J.M., 2007, Going beyond panaceas, Proceedings of the National Academy of Sciences of the United States of America, 104(39): 15176-8. [http://doi.org/10.1073/pnas.0701886104].

Parris T.M. \& Kates R.W., 2003, Characterizing a sustainability transition: goals, targets, trends, and driving forces, Proceedings of the National Academy of Sciences of the United States of America 100: 8068-8073. [http://doi.org/10.1073/pnas.1231336100].

Rittel H.W. \& Webber M.M., 1973, Dilemmas in a General Theory of Planning, Policy Sciences 4(December 1969): 155-169.

Rockström J., Steffen W., Noone K., Persson Å., Chapin, III, F.S., Lambin E., Lenton T.M., Scheffer M., Folke C., Schellnhuber H., Nykvist B., De Wit C.A., Hughes T., van der Leeuw S., Rodhe H., Sörlin S., Snyder P.K., Costanza R., Svedin U., Falkenmark M., Karlberg L., Corell R.W., Fabry V.J., Hansen J., Walker B., Liverman D., Richardson K., Crutzen P. \& Foley J., 2009, Planetary boundaries: exploring the safe operating space for humanity, Ecology and Society 14(2): 32; A safe operating space for humanity, Ecology and Society 14(2). [http://doi.org/10.1038/461472a].

Spangenberg J.H., 2011, Sustainability science: a review, an analysis and some empirical lessons, Environmental Conservation 38(03): 275-287. [http://doi.org/10.1017/ S0376892911000270].

Tainter J., 2010, A Framework for Sustainability, World Futures: The Journal of Global Education, (May 2013): 37-41. [http://doi.org/10.1080/02604020390202109].

UN, 1987, Brundtland report. United Nations, United Nations Publications, New York.

UNEP, 1972, Report of The United Nations Conference on The Human Environment, United Nations Environment Programme, Stockholm.

Wiek, A., Withycombe L. \& Redman C.L., 2011, Key competencies in sustainability: a reference framework for academic program development, Sustainability Science 
6(2): 203-218. [http://doi.org/10.1007/s11625-0110132-6].

Yarime M., Takeda Y. \& Kajikawa Y., 2009, Towards institutional analysis of sustainability science: a quantita- tive examination of the patterns of research collaboration, Sustainability Science 5(1): 115-125. [http://doi. org/10.1007/s11625-009-0090-4]. 